\title{
PANJI TRADITION IN THE JARANAN JOR AND WAYANG TIMPLONG PERFORMANCE ARTS IN EAST JAVA
}

\author{
Trisna Kumala Satya Dewi* \\ (Faculty of Humanities, Airlangga University)
}

\begin{tabular}{ll}
\hline A R T I C L E I N F O & A B S T R A C T \\
\cline { 2 - 3 } $\begin{array}{l}\text { Keyword: } \\
\text { panji tradition, }\end{array}$ & The people of East Java are still familiar with Panji tradition as their collective \\
performance art, & memory. Panji tradition is actualized in the form of art performances, such as Jaranan \\
jaranan jor, & Jor (Blitar) and Wayang Timplong (Nganjuk). Jaranan Jor and Wayang Timplong are \\
wayang timplong, & still often performed for various purposes which mean that both are still functional in \\
East Java & society. This paper aims to reveal the Panji tradition in performing arts in East Java, \\
& especially Jaranan Jor (Blitar) and Wayang Timplong (Nganjuk). It also tries to reveal a \\
& shift of the function of both performances based on their actualization in today's \\
& society. Jaranan Jor has changed its function in society, from the function of ritual \\
& ceremonies into entertainment (spectacle) function. Wayang Timplong is still \\
& functioning as a ritual ceremony of Nyadran (village cleaning). However, Wayang \\
& Timplong also serves as entertainment as well as various social communal activities \\
& such as marriage, circumcision, nadar etc.
\end{tabular}

\section{INTRODUCTION}

In East Java, the tradition of the Panji story still lives in many societies such as Wayang Topeng Malangan, Wayang Krucil (Ngawi), Wayang Beber (Pacitan), Wayang Tengul (Bojonegoro), Kethek Ogleng and Andhe-andhe Lumut (Tuban), etc. Another tradition of the Panji in East Java is performing arts namely Jaranan Jor (Blitar) and Wayang Timplong (Nganjuk). Both types of performing arts still exist in Blitar and Nganjuk areas.

Jaranan Jor is preserved by the people of Sukorejo Village, Sutojayan Subdistrict, Blitar Regency, East Java. The show performed by 17 dancers is divided into four sessions. Each session describes the messages and symbols presented by the dancers. This kuda lumping dance has philosophical meaning.

Wayang Timplong is one of the specific arts, original and only exists in the area of Nganjuk, East Java. In contrast to the puppet show (wayang purwa) that takes the source of literature from Mahabharata and Ramayana, Wayang Timplong takes a theme from local history, babad, or oral tradition. The highly popular Wayang Timplong act is taken from Panjistories such as Sekartaji Kembar. Wayang Timplong is performed in Nganjuk and its surroundings in weddings, circumcision, Thanksgiving, traditional rituals, and others.

This paper aims to reveal Panji's tradition in performing arts in East Java, Jaranan Jor (Blitar) and Wayang Timplong (Nganjuk). It also seeks the function of those performing arts in the community. From the historical point of view, the functions of ritual and entertainment of both performing arts are shifted or fixed.

\footnotetext{
* Corresponding author.

E-mail addresses: trisnadewi22@yahoo.com (Trisna Kumala Satya Dewi)
}

ISSN : 2597-7385 (Online) - ISLLAC : Journal of Intensive Studies on Language, Literature, Art, and Culture is licensed under Creative Commons Attribution-ShareAlike 4.0 International License (http://creativecommons.org/licenses/BY/4.0/). 


\section{METHOD}

In the preface of the dissertation, Edi Sediyawati said that the study related to Javanese performing arts is an updating of data about a Javanese performing arts group. Study (dissertation, thesis, research) from one aspect can be seen as a focusing on a wide survey covering the entire Javanese cultural area, which had been done by Th. Pigeaud in 1938 published Javaanche Volksvertoningen. As a study more focused on the so-called "folk show", a performance class that is not only a single standard and not promoted by a cultural center as well as a political center, then what presented in a survey is a wide variation of the people's performances (Prihatini, 2008: vii-viii).

The traditional folk performances have their own peculiarities. Koentjaraningrat (1984) says that every subculture of Javanese culture has its own characteristics; it shows the existence of an interesting social-cultural transformation as the characteristics of the people's performances (see also Prihatini, 2008:11). Art is an expression of beauty as well as the necessities of society. How arts are born and preserved is the reflection of the idea and the fantasy of the supported community. Kayam (1981:60) says that folk art was originally created by a member of society and then the local community claimed to be the owner. Folk art is functional for its people. Thus, the study of the art cannot be separated from the cosmos's whole interest. The statement reflects the function of folk art in its supporting society as entertainment as an expression of gratitude to the creator of the universe (Kayam, 1981; Prihatini, 2008:12).

Pigeaud, a Dutch scholar of Javanese culture, published "Javanese People's Performing Arts" (JavaanseVolksvertoningen) which contains information about the forms of folk art performances developed in Java (West Java, Central Java, Special Region of Yogyakarta, and East Java) and Madura around the 1930s. Pigeaud classifies the performing arts of the people into seven, as follows (1) The mask dance drama, (2) Frightening creatures mask performances, (3) Kuda Lumping, (4) Taledhek, (5) Islamicthemed Dance and Singing, (6) storyteller performances (epic story recitation), and (7) shadow puppet show (Soedarsono, 1985b: 47; Pigeaud, 1938).

Soedarsono (1985a:18) says that the performing arts historically has three functions for human life. First is as a means of ritual, second as entertainment (personal) and third as a spectacle. Although the function sare shift from ritual, personal entertainment, the spectacle, however, in this modern age the oldest function still endures. The function of performing art shifts but not the shape. Some of the functions are shifting and the shape changes or overlaps. On the other hand, there are new forms of performing arts due to human needs and creativity. Based on research that has been done, the opinion of Soedarsono(1985a) is still relevant to the present era. As an example of Dewi's research (2009) in a dissertation entitled, "Transformation of the Myth of Dewi Sri in Javanese Society", wayang purwa performance with the stories of Sri Mulih or Sri Sadana is still performing as a ritual ceremony of bersib desa.

The social function of art/artistic expressions, whether the "noble" or "entertainment" art, in addition to the aesthetic or entertainment value, must have it's social functions. What are social needs filled with the making or presentation of the works of particular artists. The artistic activity itself is the fulfillment of what society demands, how certain artistic relationships have "given direction" to art activities (Sedyawati, 2007:131).

Methods in the research of Panji tradition in Jaranan Jor and Wayang Timplong performing arts are as follows.

1. Location. The locations are East Java, especially Sukorejo Village, Sutojayan Sub-district, Blitar Regency and Besuk, Sukorejo village, Loceretsub-district, Nganjuk Regency. The research objects are the people designated as informants. Sydow (in Dundes 1965:216) states that in society there are active bearers of tradition and passive bearers of tradition.

2. Data collection. The research data are performing arts in East Java, especially Jaranan Jor, in Sukorejo Village, SutojayanSubdistrict, Nganjuk Regency and Wayang Timplong with Sekartaji Kembar act in Besuk, Sukorejo Village, Loceret Subdistrict, Nganjuk Regency. The data of this research were obtained from sources, ie those who have been defined as informants. The research data were collected by the following techniques. (1) Literature study; theoretical and methodological concepts can be obtained by studying and reading of books, journals, and materials related to the research objectives (Sutarto, 1997: 20; Dewi, 2017a:136). (2) Field study, data collected from designated research sites, namely Sukorejo Village, Sutojayan District, Blitar Regency and Besuk Sub-Village, Sukorejo Village, Loceret District, Nganjuk Regency. (3) Documentation. In the research of the oral

14 | ISLLAC : Journal of Intensive Studies on Language, Literature, Art, and Culture 
tradition of performing arts, documentation is very important. The oral tradition researcher needs to provide data in the form of written or documented text. Research with the purpose of documentation is a fieldwork. There are three stages that must be done by the researchers of field work, ie the preresearch stage, the research on location stage, and the making of manuscripts for documentation and analysis (Danandjaja 1991: 191-209; see also Dewi, 2017a:136).

\section{FINDINGS}

\section{Jaranan Jor Performance}

Jaranan Jor is a traditional performing art that is still preserved by Blitarsociety especially in Sukorejo Village, SutojayanSubdistrict, Blitar Regency, East Java. Jaranan Jor exists likely since around 1900. This art is actually originated from Tulungagung but is preserved by Blitar society and claimed to the people of Sukorejo Village.

Jaranan Jor dance is played by 17 persons including musical instruments players and dancers. Jaranan Jor performance is divided into three parts, namely tayungan dance, barongan dance, dedet melet dance. The duration of the show is about 7-8 hours, but in certain situations or by demand, performance can be about 3 hours.

\section{Tayungan Dance}

The first part is Tayungan Dance which tells about Jenggala Kingdom warrior (Kediri) who was sent by the king named PrabuAmiluhur to find his missing daughter named Dewi Sekartaji. Dewi Sekartaji seemed fled to the forest. the dance depicted the soldiers Jenggala rode, ie by dancing kuda lumping. On the way to the jungle, Jenggala's soldiers met with other soldiers and there was a war. Finally, Jenggala's warriors managed to divert the battle by moved away and avoided the attacks of other soldiers.

\section{Barongan Dance}

Barongan dance depicted the Jenggala warriors who rode further into the forest. In this section illustrated the emergence of the figure of a dragon-headed lion, called Singo Barong. Singa Barong figure is just waking up from his sound sleepiness nest and search for prey. Singo Barong then enters the village and disturbs the villagers. The prolonged dry season causes the mouth Singo Barong always gaping and "thirst" to find prey. Singo Barong went in and out of villages to search for prey, rob farmers' crops, and disturb villagers.

On its way, Singo Barong met six soldiers of the Kingdom of Jenggala and fight them. There is a fierce battle between Singo Barong and six Jenggala warriors. Eventually one by one Jenggala warrior died. A surviving Jenggala warrior fled and escape from Singo Barong's attack.

\section{Dedet Melet Dance}

The third part of Jaranan Jor is a dance of Dedet Melet. This is the highlight of Jaranan Jor. This dance depicts a dog and a pig which always fight over food. A dog in this dance has a handler and always obeyed the will of the handler.

At the end of Jaranan Jor show, dog and pig are fighting over food. When the handler gives food only to the dog, the pig is the rage with anger. The pig blindly ate everything in front of him.

\section{Musical Instruments, Offerings, and Jaranan Jor Costume}

The musical instrument used in Jaranan Jor consists of several instruments, namely gong, drum, angklung, kempul, kenong, angkrik, and slompret. Singers (penembang) are also needed in Jaranan Jor show.

The offerings in the traditional show are usually required as the completeness of a performance ritual. Similarly, Jaranan Jor. Completeness offerings in Jararan Jor show are black chicken (alive), white rice, flowers, the fruit of plantains, coconut, flower arrangement, water nira (badeg), beras kencur, and green beans. The variety of offerings means that Jaranan Jor shows hope of avoidance from catastrophe.

The music was sounded before Jaranan Jor dancers came out in the arena of the show - the sound of the (kendang) drum playing as the orchestra guides. The sound of the drum is a gesture for the dancers to change the form of the dance. The drum is resounding flat tones, "tungtaktungdor, tungtaktungdor, tang, tang, dor, tang, tang, dor". 
Six dancers as Jenggala warriors follow the music as the opening the performances. The dancers dressed in Jaranan Jor's typical costume, namely udeng (head binder), red handkerchief worn around the neck, white T-shirt, setagen (black girdle wrapped with a belt). The composition of three colors, white, red, and black, dominates Jaranan Jor show. Jaranan dancers wear knee-length trousers, jarik (Javanese clothes) with barong motifs. The dancers mount a kuda lumping (horse made of woven bamboo) and use black glasses. Jaranan Jor dancer resembles the dashing cavalry warriors.

After the opening dance is completed, the handler enters the area of the show bringing the carapace (anglo) which contains the charcoal sprinkled with incense. This illustrates the symbolic white, red, and black elements - as used in Joranan Jor costume. Colors symbolize the white color (seto) describes humans born in a holy and innocent state. The red color (wreto) symbolizes that a baby born in the world will live experiencing many problems and challenges. The black color is a symbol of ugliness; the bad things in the human world that must be faced and fought to achieve the perfection of life.

\section{Wayang Timplong Performance}

Wayang Timplong is a traditional folk art of Nganjuk region and only grown and preserved by Nganjuk and surrounding communities. Wayang Timplong is performed in various social events such as cleaning village ceremony or nyadran, ruwatan, nadar, and events in a certain or considered sacred place (Harimintaji, et.al. 1994:213).

The stories in the Wayang Timplong show are different from another wayang, such as wayang purwa that derived from the Mababharata and Ramayana stories. The themes of the Timplong story are based on historical stories such as babad and local traditions. The well-known and favored theme is the story of Panji in its various versions.

Performing arts and literary arts in Javanese culture have developed side by side and interplay between them. Many literary works born and refer to the story in the performing arts. Panji's story became the repertoire of several performing arts, in both Central and East Java, for example, Topeng Dalang (WayangTopeng) Malangan, Wayang Beber Pacitan, Wayang Krucil, Wayang Tengul, dance (beksa), Kethek Ogleng and Andhe-andhe Lumut (Tuban) (Sudikan, 2013: 3). Another type of puppet is Timplong puppets, originating from Nganjuk, East Java.

Wayang Timplon gwith Panji story is still often performed by a puppeteer from Nganjuk area. Panji story in Timplong show is Sekartaji Kembar, Sekartaji Murco, Semoro Bangun Murco (Asmara Bangun Murco). Besides Panji story, the themes come from local stories (Babad Tanah Jawi) is the story of Demak Mosque. Timplong themes that come from historical events, called the Majapahitan, are Damarwulan, Jaka Umbaran, and Bujang Ganong. The stories from local traditions are Laire Baru Klinthing, Jaran Awang, Laire Jaka Slewah, Jaka Ombak, Jaka Lara, and others.

\section{Wayang Timplong and Nyadran Tradition}

Besides performed in various social celebrations such as weddings, circumcision, and nadir, Wayang Timplong is also carried out in ritual ceremony nyadran or clean village. Nganjuk local community practice nyadran tradition every year usually in the month of Sura (Muharram). Nyadran is a hereditary tradition that must be implemented by the Javanese community as an expression of gratitude to God Almighty, the Creator of the universe.

Pigeaud (1960-1963) connects the term sraddha with the term in New Javanese, "nyadran". This term refers to visiting family grave once a year in the Muslim tradition. Nyadran is an imperfect form of "sraddha". This ritual comes from deep and widespread ancestor worship in the archipelago of Indonesia (see also Kieven, 2014: 106). Sraddha in Banawa Sekar poetry also features flowers (Zoetmulder, 1985: 449-50). Nyadran in Sura (Muharram) is still implemented by Nganjuk local community. The Timplong puppet show is an obligation show to the traditional ritual as implemented by the people of Dusun Besuk, Sukorejo Village, LoceretSubdistrict, Nganjuk Regency (Friday, 6 November 2016) (Purwaningsih, 2016:17). The ritual here is usually carried out for three consecutive days, starting from cleaning at each resident's house up to the village environment. The spiritual activities are tablil (pray) in a house of the resident and congregation in mushola (small mosque).

On the last day of nyadran, people hold an activity in a place that has been determined. The location is an area that is considered as a place Danyang (magical creature) or cemetery, tomb, or a sacred place to pray together. All people in Dusun Besuk bring food and hand over to the committee. Foods 16 | ISLLAC : Journal of Intensive Studies on Language, Literature, Art, and Culture 
brought on nyadran ritual are rice, gudangan, side dishes such as eggs, sambal goreng, tofu, and tempe. Ingkung ayam (cooked whole chicken) and plantain are a complement to the ritual food. In that tradition, the elders, modin, village chief (lurah), gathered together with citizens to pray together led by a modin. A joint prayer is offered by the people of Dusun Besuk to ask sustenance, health, welfare, and be kept away from danger.

The essence of nyadranis an expression of gratitude of the people of Dusun Besuk on the gift of God Almighty of the abundance of sustenance, welfare, and public safety. Praying of the community ends the nyadran ritual. The food that has been collected and prayed by Modin then distributed to the people. The people then enjoy the food in an atmosphere of togetherness and some people bring home their food.

\section{The Twin Sekartaji (Sekartaji Kembar)}

In the nyadran ritual ceremony in Dusun Besuk, the Sekartaji Kembar of Panji story is performed. The timplong puppet show is performed in the place of the elderly (Kamitua) of Besuk Village, Sukarejo Village, Loceret Sub-district, Nganjuk Regency. Before the Timplong began, the people of Dusun Besuk held a Thanksgiving event in front of the stage. Tumpeng that contains rice and complete side dishes are enjoyed together by villagers, puppeteers, and Timplong puppet performers.

After that, gamelans rounds indicates that Timplong puppet show with the Sekartaji Kembar act will begin soon. Dalang (puppeteer) named Ki Suyadi comes from Dusun Bongkal, Kepanjen Village, Pace District, Nganjuk. The duration of Timplong puppet show is about 7-8 hours, which starts around at 09.30 -- at 17.00 with break time to perform the worship prayer (dhuhur and ashar).

\section{The Story of Sekartaji Kembat ${ }^{t}$}

Sekartaji Kembar is one of Panji stories. The story begins with the background of the kingdoms in East Java, the Kingdom of Kediri ruled by a king named Lembu Amijaya who had a daughter named Sekartaji. One day, a man called Danyang Bramingjaya from Sebrang country proposed to Sekartaji. He arrived with all the tributes of gold and properties (Java: rajabrana) with the intention that his proposal is accepted. Conversely, if rejected there will be war in Kediri.

Raja Lembu Amijaya was very upset and called all of his ministers. Lembu Amijaya decided to reject Danyang Braminjaya proposal and there was a war between Kediri and Sebrang kingdom. Patih Kenaka, the prime minister of Kediri Kingdom, ordered Peksi Raga to block King Jaka and his soldiers from Sebrang. Prabu Jaka is finally lost and returned to Sebrang kingdom.

Danyang Bramingjaya had another way to realize the will of Prabu Jaka and Dewi Rara Sumekar. Danyang Bramingjaya used his magic to transform Dewi Rara Sumekar into Dewi Sekartaji. Later, Prabu Jaka was able to bring the original Sekartaji to his country and exchanged with fake Sekartaji in Kediri.

Prabu Jaka and Dewi Rara Sumekar managed to fool Panji Asmara Bangun with fake Sekartaji. However, the trick was known by Kedrah and Gepuk Miri-which were eventually expelled from Kediri. Kedrah had a plan to find the original Sekartaji by meditating in the forest by asking for help Kanjeng Pinulun in Kabyangan. After arriving at Kabyangan, Kedrah given heirloom named "lapdhajiwa" and told to explore the village Milangkori. In Sebrang kingdom, Prabu Jaka asked real Sekartaji to be the queen. Sekartaji requested the show with Dalang Sapa Nyana as a requirement. Prabu Jaka then ordered his minister named Patib Pratala to find Dalang Sapa Nyana.

Patih Pratala finally found Dalang Sapa Nyana and Gepuk Miri. Dalang Sapa Nyana was invited to the Sebrang kingdom and met the real Sekartaji. Prabu Jaka again insisted Sekartaji to accept his proposal. Sekartaji avoided by biding the time with Dalang Sapa Nyana. Hyang Pikulun then rescued them by making all the soldiers, the ministers, and Prabu Jaka sleeping. Gepuk Miri took Sekartaji fled to the forest.

The middle of the forest became a hideout of Kedrah, Gepuk Miri, and real Sekartaji. Sekartaji felt her pregnant. Later, she gave birth to a boy named PanjiLaras. Meanwhile, in Kediri, fake Sekartaji also gave birth to a baby in the form of giant (Javanese: buta). Panji Asmara Bangun was very surprised to see the child and then named him Jaka Sembada.

$+\quad$ See Purwaqningsih (2016: 213-217) 
Jaka Sembada has become an adult and one day wanted to hold a cockfighting competition. Panji Laras heard the announcement and joined the competition in the city square. Jaka Sembodo's rooster finally died defeated by Panji Laras rooster. Jaka Sembada broke his promise to give a prize to the winner, Panji Laras. Finally, there was a fierce battle between them and Jaka Sembada died after losing the fight (see also Dewi, 2017b).

After the fight was over, Kedrah, Gepuk Miri, and the real Sekartaji approached Panji Asmara Bangun. He very surprised to see the two Sekartaji (Sekartaji twins), the real and the fake. Kedrah revealed the truth that Sekartaji on his side is Dewi Rara Sumekar. Panji Asmara Bangun then apologized to Kedrah and real Dewi Sekartaji for having been blinded and unable to see the truth. Panji Asmara Bangun finally found out that Panji Laras was his son. They finally live happily together in the secure Kediri Kingdom.

\section{DISCUSSION}

In East Java, the Panji tradition is still widely recorded and actualized in the performing arts. For example, Jaranan Jor and Wayang Timplong with Panji story in the act of Sekartaji Kembar. The basic theme of the story is the adventure and suffering of Raden Panji, son of Kauripan before marrying his cousin, Princess Candra Kirana from Daha. This theme in all the Panji stories is the same, but in each story always worked differently (Ras, 2014:223-224).

Jaranan Jor, in association with Pigeaud's (1938) research on folk performances in Java (East Java), is included in the type of kuda kepang or jathilan show. The Timplong puppets are included in the Wayang Kulit category-that may be unfit. However, both Wayang Timplong and Wayang Kulit are played by a puppeteer, the existence of wayang, gamelan (nayaga), and Sinden. The difference is the wayang medium. Wayang Timplong is made of wood and uses no kelir (screen background), while Wayang Kulit is made of animal skin (cow) and uses a white screen - shadow show. The performing arts in East Java, both Wayang Timplong and Jaranan Jor are not found in Pigeaud's research (1938). Nevertheless, from the historical side, the two types of art remain a part of the diversity of the performing arts of East Java.

The Panji tradition in East Java is different from Panji's tradition in Central Java in terms of the creation of his work and genre. In East Java, the Panji tradition is more actualized in the performing arts, while the Panji tradition in Central Java is widely recorded in the tradition of script writing. However, is also shown in performance arts such as kethoprak, wayang orang (wayang wong), wayang beber. Ras (2014: 224) says that the story of Panji Jawa Tengahan is composed in the middle. There are also younger variants in the matra macapat, the stories are not dated. From his paintings, it appears that poets work in the palace environment with tradition, In this case, Rasargues that with regard to the preparation of the flow, it appears the author is less aware of the geography and chronology of Java. The story always prevails in Java and the Kingdoms of Koripan (Janggala) and Daha (Kediri) always appear, it can be concluded that the origin of the Panji theme is indeed from Java and in the period when the two kingdoms are ruled by a single king. Panji's tradition in Java is more interesting than the Panji tradition in Bali.

Jaranan Jor or Jatbilan and the like, originally functioned as a ceremonial dance to summon totem animals. In the present era, it turns into a secular spectacle that accentuates the supernatural acts performed by dancers who are in a state of trance. The term Jathilan refers to horses. Njathil means "dancing and running" specifically for horses (see Soedarsono, 1985b:54-55). The mention of Jaranan Jor (including Jathilan or KudaKepang) for the performance art in Blitar, East Java is a unique terminology, such as oglek (Bantul), Incling (Kulonprogo), Jathilan Pitik. Walik (Magelang), Jelantur (Boyolali), Ebleg or Embleg (Banjarnegara). Reog is the type of folk performance that has Jathilan dance.

In its further development, there was a new interpretation and development of the Jathilan. Jathilan was originally a show of rituals for the salvation of the village, then changes tospectacle that featured supernatural acts and eventually evolve into a war dance. Jathilan is regarded as a dance depicting a knight who rode the horse. To accentuate his knightly character, the horseman dancers are armed with a sword. The climax of the show was the trance in the war scenes. Then the story is blended into the show. In general, in villages that have Jathilan tradition, the horseman's knight is the warrior of the Panji story. The selection of Panji's story can be seen in the appearance of two Panji men, Penthul (white masked) and Tembem (black masked) (Soedarsono, 1985b:55).

In Jaranan Jor performance begins with dances called Tayungan, which is a kuda lumping horse depicting Janggala Kingdom soldier who was sent by his king named Prabu Amiluhur to find his daughter, 18 | ISLLAC : Journal of Intensive Studies on Language, Literature, Art, and Culture 
Dewi Sekartaji who fled to the forest. Then the show continued with Barongan dance, the emergence of Singo Barong, the figure of robbers who are thirst and hunger to prey on whatever he encounters. Singo Barong then goes into the forest and prey the plantation of the village farmers. The six soldiers meet with Singo Barong and there was a fierce battle. Finally, the six Jenggala warriors escaped from Singo Barong. Jaranan Jor's last show was the Dedet Melet dance - this dance was the highlight of Jaranan Jor's show depicting a fierce battle between a dog and a pig. The dog is very obedient and followed what is ordered by the handler. Once, the handler feeds his dog but not the pig. The pig went on a rampage and ate everything.

Based on the historicity, Jaranan Jor, which now becomes the art ofBlitar community (Sukorejo Village, SutojayanSub-district) came from Tulungagung, East Java. Around the 1900s, the village of Ngasinan (Tulungagung) area experienced a prolonged drought. People then held a rainy ritual ceremony accompanied by Jaranan Jor art performance. It can be concluded that JorananJor art performance originally was a mean of the ceremony to ask for rain. The ritual then shifted into a spectacle or entertainment in the area of Blitar. Jaranan Jor show performance changed from ritual art to the art of spectacle, but the shape is still permanent.

The tradition of Panji in Wayang Timplong show inNganjuk is used as a means of the ceremony of nyadran. The time of the story of Panji was studied by CC Berg in his book, "Inleiding tot de Stuidie van het Oud-Javaansch" that stated the spread of Panji's stories in Nusantara (not the year of its creation). As the beginning year is Pamalayu (1277 AD) and as the final year is approximately 1400 AD. Berg argues that the Panji stories in Old Javanese are translated or adapted in Malay (Poerbatjaraka, 1968: 493).

In 1930 Berg argued that the hero stories (the Panji story) from Java might have been popular in the palace of the kings of East Java, but by Hindu followers, this tradition was pressed and then developed in Bali. However, Berg's opinion is disputed by Poerbatjaraka as something too quickly concluded. The Pamalayu event to define the Panji tradition is still too fast because the memory of Singasari, Kediri-Daha is still attached, so that if this tradition has been written it will not be accepted in society. The tradition was written exactly when the memory of Singasari was vague. At that time, it was not unusual for Singasari was at the same time with Kediri-Daha in the Panji and Candra Kirana stories (Poerbatjaraka 1968:404). Thus, in this case, Poerbatjaraka (1968) argues that the early writing of Panji's story was in the Majapahit triumph. The spread of Panji's story to the islands or other areas took place much later.

The Sekartaji Kembar in the Wayang Timplong is part of Panji tradition that still lives in East Java, especially Nganjuk area. Other Panji stories are Semoro Bangun (Asmoro Bangun) and Sekartaji Murca. Panji in Wayang Timplong is in collective memory of puppeteer Wayang Timplong in Nganjuk area, Ki Suyadi (Dusun Bongkal, Pace Village), Ki Sutikno (DusunJetis, Pace Village), Ki Jikan (DusunJetis, Pace Village), Ki Mursito (Getas Village), Ki Budi (DusunBanaran, Getas Village) (Purwaningsih, 2016: 22-23).

The Panji tradition in the Wayang Timplong puppets in the Nganjuk area function as a ritual ceremony of nyadran. Nowadays, the function of the performing arts is still as a ritual of nyadran. The form of performance art is also fixed- with its variants. Thus, the function and form of the show were fixed. In addition to performing arts and as a means of the ceremony, Wayang Timplong also serves as a spectacle, as a means of entertainment in the community. Sekartaji Kembar tells about the adventure and re-meeting of Panji Asmoro Bangun and his wife Dewi Sekartaji. He also met his son, Panji Laras, who managed to win a chicken fighting competition.

\section{CONCLUSION}

Panji tradition in performing arts in East Java is still actual and functional in the community of Blitar with Jaranan Jor and Nganjuk with Wayang Timplong especially the act of Sekartaji Kembar. Panji tradition or the themes from Panji's story is still attached as a collective memory of society East Java and realized in the form of performing arts such as Jaranan Jor (Blitar) and Wayang Timplong (Nganjuk).

Jaranan Jor as performing arts in Blitar and surrounding areas initially functioned as a means of ritual ceremony. However, in the present era, it is more functioning as a spectacle or entertainment. In this case, Jaranan Jor form does not change, but the function does.

Wayang Timplong as performing arts in Nganjuk and surrounding areas serves as a means of nyadran ritual ceremony. Besides as a means of ritual ceremony, Wayang Timplong (Sekartaji Kembar play) also serves as entertainment on social congregation such as wedding celebration, circumcision, nadar, and so 
on. In this case, Wayang Timplong performances still function as a means ritual ceremony. Along with the development, the Wayang Timplong in terms of the art form has not changed but still shifting. Besides as a ritual ceremony, Wayang Timplong also serves as entertainment or spectacle. Wayang Timplong in its function as a spectacle carries out function as social binding.

\section{REFERENCES}

Danandjaja, J. (1991). Folklor Indonesia Ilmu Gosip, Dongeng, dan Lain-Lain. Jakarta: Grafiti Pers.

Dewi, T. K. S. (2009). “Transformasi Mitos Dewi Sri dalam Masyarakat Jawa”. Disertasi. Depok: Fakultas Ilmu Pengetahuan Budaya Universitas Indonesia.

Dewi, T. K. S. (2017a). Menelusuri Jejak Tradisi Lisan Jawa Timur.Prosiding.Seminar NasionalPerspektif Bahasa, Sastra, dan Budaya Indonesia Dalam Menghadapi Tantangan Global. Surakarta: Keluarga Alumni Prodi Sastra Indonesia dan Prodi Sastra Indonesia Fakultas Ilmu Budaya Universitas Sebelas Maret.

Dewi, T. K. S. (2017b). "Reconstruction of Traditional Art of Wayang Timplong as Local Wisdom of Nganjuk East Java Community" in Local Wisdom for Sustainable Development. International Conference on Sumatera's Local Wisdom. Medan: Sekolah Pascasarjana Universitas Sumatera Utara.

Dundes, A. (1965). The Study of Folklore. Englewood Cliffs, N.J., Prentice-Hall Inc.

Harimintaji, et al. (1994). Nganjuk dan Sejarabnya. Nganjuk: Penerbit Keluarga.

Kayam, U. (1984). Seni, Tradisi, Masyarakat. Jakarta: Sinar Harapan.

Kieven, L. (2014). Menelusuri Figur Bertopi dalam Relief Candi Zaman Majapahit. Jakarta: Kepustakaan Populer Gramedia.

Koentjaraningrat. (1984). Metode-Metode Penelitian Masyarakat. Jakarta: Gramedia Pustaka Utama.

Pigeaud, Th. (1938). Javaanse Volksvertoningen. Batavia: Volkslectuur.

Pigeaud, Th. (1963). Java in the $14^{\text {th }}$ Century: A Study in Cultural History. (5 jilid) The Haque: Nijhoff.

Poerbatjaraka. (1968). Tjerita Pandji dalam Perbandingan. Jakarta: Gunung Agung.

Prihatini, N. S. (2008). Seni Pertunjukan Rakyat Kedu. Surakarta: ISI Press dan CV Cendrawasih.

Purwaningsih, L. (2016). "Wayang Timplong Lakon Sekartaji Kembar dalam Tradisi Nyadran Desa Sukorejo Kabupaten Nganjuk: Sebuah Analisis Struktur dan Fungsi bagi Masyarakat Pendukungnya". Skripsi. Surabaya: Fakultas Ilmu Budaya.

Pigeaud, Th. (1938). Javaanse Volksvertoningen. Batavia: Volkslectuur.

Ras, J.J. (2014). Masyarakat dan Kesusastraan di Jawa. Translated by Achadiati Ikram. Jakarta:Fakultas Ilmu Pengetahuan Budaya UI, Yayasan Naskah Nusantara (Yanassa), Yayasan Pustaka Obor Indonesia.

Sedyawati, E. (2007). Budaya Indonesia Kajian Arkeologi, Seni, dan Sejarah. Jakarta: PT Raja Grafindo Persada.

Soedarsono, R.M. (1985a). "Peranan Seni Budaya dalam Sejarah Kehidupan Manusia Kontinuitas dan Perubahannya". Pidato Pengukuhan Guru Besar. Yogyakarta: Universitas Gajah Mada.

Soedarsono, R.M. (1985b). "Pola Kehidupan Seni Pertunjukan Masyarakat Pedesaan" Dalam Gaya Hidup Masyarakat Jawa di Pedesaan: Pola Kehidupan Sosial Ekonomi dan Budaya. Yogyakarta: Departemen Pendidikan dan Kebudayaan

Sudikan, Y. (2013). "Kearifan Lokal dalam Cerita Panji (Resepsi Pembaca" Dalam dan Luar Negeri terhadap cerita Panji)". Makalah.Seminar Bahasa dan Sastra. Bangkalan: Universitas Trunojoyo.

Sutarto, A. (2007). Legenda Kasada dan Karo Orang Tengger dan Lumajang . (Disertation). Jakarta: Fakultas Sastra Universitas Indopnesia.

Zoetmulder, P. J. (1985). Kalangwan: Sastra Jawa Kuno: Selayang Pandang. Jakarta: Djambatan. 